\title{
Risk of cancer from the use of tar bitumen in road works
}

\author{
U KNECHT, H-J WOITOWITZ
}

From the Institute and Outpatient Clinic for Occupational and Social Medicine of the Justus-Liebig-University of Giessen, 6300 Giessen, Federal Republic of Germany

ABSTRACT Tar bitumens are increasingly being used as a binder in road works. They consist of aç standard product of about $70 \%$ bitumen and $25-30 \%$ tar. Tar bitumens are classifiable as theo pyrolysis products of organic materials and are applied hot. Depending on the temperature used there are emissions of various intensities of polycyclic aromatic hydrocarbons (PAH), some of which arei carcinogenic. A total of 250 one hour air samples was taken at breathing height on 20 days at 11 road $^{\circ}$ works sites. The region of road paving operations in the immediate neighbourhood of the finishingi machine operator and the screedmen were the chosen sampling points. A total of 19 unsubstitutedo PAH in the PAH complex present in the air samples was quantitatively determined by means of gas chromatography/mass spectrometry. These included benzo[b]fluoranthene, benzo[a]pyrene, chrysene, dibenzo[a,h]anthracene, and indeno[1,2,3-cd]pyrene, all of which are carcinogenic. The median concentrations of chrysene and of benzo[b,j $+\mathrm{k}]$ fluoranthenes (determined en masse) were $9 \cdot 3$ and $2 \cdot 8 \mu \mathrm{g} / \mathrm{m}^{3}$ respectively. The median concentrations of benzo[a]pyrene (BaP) and $\vec{\oplus}$ indeno[1,2,3,-cd]pyrene were 0.7 and $0.2 \mu \mathrm{g} / \mathrm{m}^{3}$ respectively. Dibenzo[a,h]anthracene had the lowesto median concentration with about $0.03 \mu \mathrm{g} / \mathrm{m}^{3}$. Of the resulting shift means, the BaP concentration we्gs over $1 \mu \mathrm{g} / \mathrm{m}^{3}$ in about $50 \%$ of the cases, over $2 \mu \mathrm{g} / \mathrm{m}^{3}$ in $35 \%$, and over $5 \mu \mathrm{g} / \mathrm{m}^{3}$ in about $15 \%$. Evên when the temperature of the paving mix was only between $120^{\circ}$ and $135^{\circ} \mathrm{C}, 4.8 \%$ of the concentrations ( $\equiv 3$ samples) were greater than $2 \mu \mathrm{g} \mathrm{BaP} / \mathrm{m}^{3}$; this value was exceeded in $34.9 \%$ of theg determinations ( $\equiv 30$ samples) when the temperature of the tar bitumen was between $135^{\circ}$ and $150^{\circ} \mathrm{C} . \bar{\Omega}$ The highest concentration measured here was $17.8 \mu \mathrm{g} \mathrm{BaP} / \mathrm{m}^{3}$. The recommended maximum paving temperature of the paving mix of $150^{\circ} \mathrm{C}$ was exceeded in about $23 \%$ of all cases. The maximum3 concentration determined under any condition was $22 \mu \mathrm{g} / \mathrm{m}^{3}$. Thus the employment of tar bitumen as? a binding material during road paving operations must be regarded as causing a considerable risk to? health. The primary task is to ascertain whether tar bitumen can be replaced as a binder in paving forō roads and what safety measures are practicable.

The places of work where the air contains polycyclic aromatic hydrocarbons (PAH) include the production and processing of high boiling residues of the dry distillation (pyrolysis) of fossil fuels. Those worthy of mention include coke works, gas works, iron foundries, and the manufacture of aluminium. ${ }^{1-4}$ Here it is mainly preparations based on coal tar or pitch that are used.

The risk of cancer to people inhaling such substances has been established ${ }^{56}$ whereas in animal experiments tars and pitches are among the classic carcinogenic materials. $^{7-9}$

Tar bitumen is used as a binder for bituminous

Accepted 18 January 1988 mixes used in road works or the laying of load bearing binding, and surface layers. Under experimental con-3 ditions it has been possible to record the evaporationo of measurable amounts of PAH emissions from tar? bitumen even at temperatures of about $100^{\circ} \mathrm{C} .^{10}$

Thus there is a presumption that PAH including carcinogenic substances will be emitted during hoto paving. Tar bitumen is a standardised producto containing about $70 \%$ road bitumen and $25-30 \%$ on "special coal tar pitch." "This pitch is produced from ${ }^{\omega}$ coal tar by a specialised process. Its PAH content corresponds to that of the tar bitumens of earlier? years. ${ }^{12} \mathrm{~A}$ tar bitumen binder known as Carbobitumeno 70 has been used in road laying for some time.

The aim of our investigation was to analyse the 
PAH profile in air samples taken at road works and to estimate the risks to health of those engaged in using Carbobitumen. We also wished to determine the benzo[a]pyrene concentrations achieved at the maximum paving temperature of $150^{\circ} \mathrm{C}$ recommended by the manufacturers.

\section{Material and methods}

\section{DESCRIPTION OF WORK AND SAMPLING METHOD}

The most important work areas of the paving machine using bituminous mixtures were included in the investigation. The air samples were made, according to the regulations, at breathing height and in the immediate neighbourhood of the machine operator and the rakerman on the screed distributor with heated flattening equipment and thus correspond to measurements made for a particular person. The driver sits on his paver about $1.50 \mathrm{~m}$ over the asphalt mix on the finishing machine platform and controls the individual functions of the machine. Whether the covered cabin is open at the sides depends on the weather. There is normally a worker to the left and another to the right of the finisher to carry out any subsidiary tasks, such as removing asphalt mix that has fallen sideways from the finisher or flattening small areas of paving. The rakerman also monitors the thickness of the paving being laid and controls the supply of new asphalt mix from trucks reversing up to the finisher.

It proved possible to determine representative $\mathrm{PAH}$ concentrations for a shift on 20 days at 11 road work sites. A total of 250 air samples was taken. Of these, 58 determinations were made in the driving cab of the finisher and 192 samples were taken in the working area around the screed distributor. The samples were collected for one hour.

The technical conditions were those laid down for the analysis process in the TRGS 402* criteria. The points these cover include the method of analysis, number, and spatial and temporal distribution of the samples to be taken together with their analytical determination. ${ }^{13}$

The analyses of the bituminous mixtures being used at a particular site for their PAH contents may, under certain conditions, allow conclusions to be made concerning the concentration of the emitted PAH. For this purpose 21 material samples were taken and included in the investigation.

\section{ANALYTICAL PROCEDURES}

The sampling equipment comprised a special filter

- Technische Regeln für Gefahrstoffe (Technical rules for hazardous materials). holder containing a glass fibre filter connected to a controlled sampling pump.

It has been shown experimentally that, despite their high boiling points, the saturated vapour pressures of some PAH are considerable. ${ }^{1415}$ This can have an appreciable effect on the results obtained even at temperatures that are to be expected at the workplaces involved. Thus if the samples are collected on filters alone losses must be expected even from particulately bound PAH, particularly when the size of the ring system is small as a result of re-evaporation from the filter. Losses caused by this blow off effect together with the gaseous PAH components present in the emissions, which are not, or not completely, retained, may be adsorbed on a collection phase comprising XAD-2 or Tenax resin connected after and in series with the filter system. We have already reported elsewhere on the reliability of this combined system. ${ }^{16}$ It makes it possible to differentiate between the PAH associated with the particulate matter collected on the glass fibre filter and the total PAH concentration of the air sample.

The material samples, the glass fibre filters used for sampling, and the Tenax or XAD-2 adsorption resins were subjected to Soxhlet extraction with boiling toluene for four hours. Further sample preparation steps were then applied to the PAH containing extracts. ${ }^{17-19}$ The qualitative and quantitative analysis of the PAH was made by capillary gas chromatography. Indeno[1,2,3-cd]fluoranthene was used as an internal standard. The individual components were identified by comparing their gas chromatographic retention times with those of reference PAH and by their mass specific detection exploiting the substance specific individual molecular masses (SIM = selected ion monitoring).

\section{CHOICE OF PAH}

The choice of the PAH used as reference substances was made on the basis of toxicological criteria and the possibility of their presence in the air at the place of work. ${ }^{6}$ The PAH included in the investigation, the abbreviations used for them in the text, melting points and boiling points, and their carcinogenic and mutagenic properties as shown in animal experiments and the Ames test respectively are listed in table 1.

The five compounds marked with an asterisk are included in the list of maximum workplace concentrations and biological tolerance values for substances at the place of work of the Deutsche Forschungsgemeinschaft. ${ }^{5}$ These substances have been unequivocally proved to be carcinogenic in animal experiments and under conditions that are comparable with those obtaining for man at the place of work. 
Table 1 The 19 polycyclic hydrocarbons (PAH) chosen for an estimate of the risk involved in the work areas of road works during the use of tar bitumen as a binder. The table includes the abbreviations, the melting and boiling points, and biological activities according to animal experiments and the Ames test; the PAH are divided according to the ring system

\begin{tabular}{|c|c|c|c|c|c|}
\hline & Abbreviation & $M P\left({ }^{\circ} \mathrm{C}\right)$ & $B P\left({ }^{\circ} C\right)$ & $\begin{array}{l}\text { Carcinogenicity } \\
\text { (animal studies) }\end{array}$ & $\begin{array}{l}\text { Mutagenicity } \\
\text { (Ames test) }\end{array}$ \\
\hline $\begin{array}{l}4 \text { Ring systems } \\
\text { Fluoranthene } \\
\text { Pyrene } \\
\text { Benzo[a]fluorene } \\
\text { Benzo[b]fluorene } \\
\text { Benzo[c]phenanthrene } \\
\text { Benzo[a]anthracene } \\
\text { Chrysene* }\end{array}$ & $\begin{array}{l}\text { FLU } \\
\text { PYR } \\
\text { BAFL } \\
\text { BBFL } \\
\text { BCPH } \\
\text { BAA } \\
\text { CHR }\end{array}$ & $\begin{array}{l}111 \\
150 \cdot 4 \\
190 \\
208-209 \\
66 \cdot 1 \\
160-161 \\
256\end{array}$ & $\begin{array}{l}383 \\
393 \\
407 \\
401-402 \\
435 \\
438 \\
441\end{array}$ & $\begin{array}{l}-; \mathrm{CC} \\
-; \mathrm{CC} \\
- \\
- \\
++; \mathrm{TI} \\
\pm /+; \mathrm{TI} \\
\pm /+; \mathrm{TI}\end{array}$ & $\begin{array}{l}+ \\
\overline{+} \\
+1- \\
\overline{+}+ \\
+ \\
+\end{array}$ \\
\hline $\begin{array}{l}5 \text { Ring systems } \\
\text { Benzo[b]naphtho[2, 1-d]thiophene } \\
\text { Benzo[ghi]fluoranthene } \\
\text { Benzo[b }+\mathrm{j}+\mathrm{k}] \text { fluoranthene* } \\
\text { Benzo[e]pyrene } \\
\text { Benzo[a]pyrene* } \\
\text { Perylene } \\
\text { Dibenzo[a,j]anthracene } \\
\text { Dibenzo[a,h]anthracene* }\end{array}$ & $\begin{array}{l}\text { BNT } \\
\text { BGHIF } \\
\text { BBJKF } \\
\text { BEP } \\
\text { BAP } \\
\text { PER } \\
\text { DAJA } \\
\text { DAHA }\end{array}$ & $\begin{array}{l}185 \cdot 8 \\
149 \\
165-217 \\
178 \cdot 7 \\
178 \cdot 1 \\
273-274 \\
197 \\
266 \cdot 6\end{array}$ & $\begin{array}{l}429 \cdot 9 \\
431 \cdot 8 \\
480-481 \\
493 \\
496 \\
497 \dagger \\
531 \dagger \\
535 \dagger\end{array}$ & $\begin{array}{l}- \\
\bar{t} /++1+++; \mathrm{TI} \\
-1+ \\
+++1++++; \mathrm{TI} \\
- \\
++ \\
+++1++++; \mathrm{TI}\end{array}$ & $\begin{array}{l}+ \\
+ \\
++1+++ \\
+ \\
++++ \\
+ \\
++1+++\end{array}$ \\
\hline $\begin{array}{l}6 \text { Ring systems } \\
\text { Indeno[1,2,3-cd]pyrene* } \\
\text { Benzo[ghi]perylene } \\
\text { Anthanthrene }\end{array}$ & $\begin{array}{l}\text { IND } \\
\text { BGHIP } \\
\text { ANT }\end{array}$ & $\begin{array}{l}163 \cdot 6 \\
278 \cdot 3 \\
264\end{array}$ & $\begin{array}{l}534 \dagger \\
542 \dagger \\
547 \dagger\end{array}$ & $\begin{array}{l}+1++; \mathrm{TI} \\
+1-; \mathrm{CC} \\
\pm 1++\end{array}$ & $\begin{array}{l}++ \\
+1- \\
+\end{array}$ \\
\hline $\begin{array}{l}7 \text { Ring systems } \\
\text { Coronene }\end{array}$ & COR & $438-440$ & $590 \dagger$ & $+/-; \mathrm{TI}$ & + \\
\hline
\end{tabular}

*Unequivocally shown to be carcinogenic in animal experiments.

†stimated from the gas chromatographic retention time.

- No evidence for animal carcinogenicity/mutagenicity.

\pm Very weakly active; + weakly active; ++ moderately active; +++ very active; ++++ extremely active

$\mathrm{TI}=$ Tumour initiator; $\mathrm{CC}=$ Cocarcinogenic with benzo[a]pyrene.

Biological activities published often differ and in some cases several reports are cited.

\section{Results}

Figure 1 illustrates the gas chromatogram of an extract obtained from an air sample collected at the workplace during road works involving the use of tar bitumen. A total of 19 unsubstituted PAH in this complex pollutant spectrum were quantitatively determined.

The means of the PAH concentrations in all 250 air samples may be found in fig 2 . They are presented with the mean PAH concentrations of the 21 samples of bitumen mix based on Carbobitumen which were

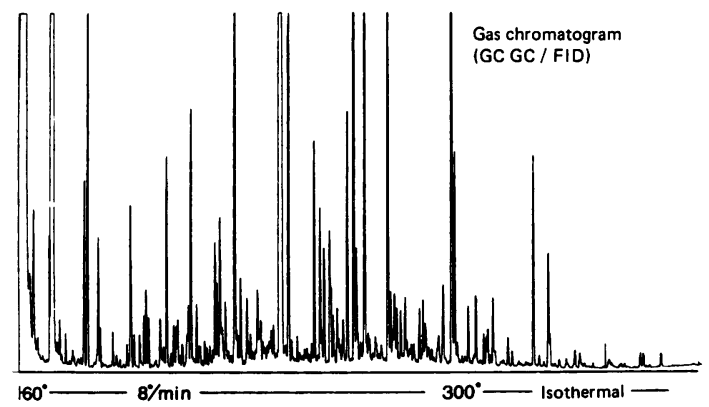

Fig 1 Glass capillary gas chromatogram (GCGC/FID) of extract of air sample taken in work area of road works during use of tar bitumen as binder. included in the investigation. The comparable PA profiles of both material samples are striking. account of the differing temperature dependenहू volatilities of the individual PAH and the considerable scatter that this causes in the atmospheric concen $\overrightarrow{\bar{O}}$ trations it is not possible to draw any conclusion\$ concerning quantitative relations. Thus the standard deviations for the PAH concentrations in the air are

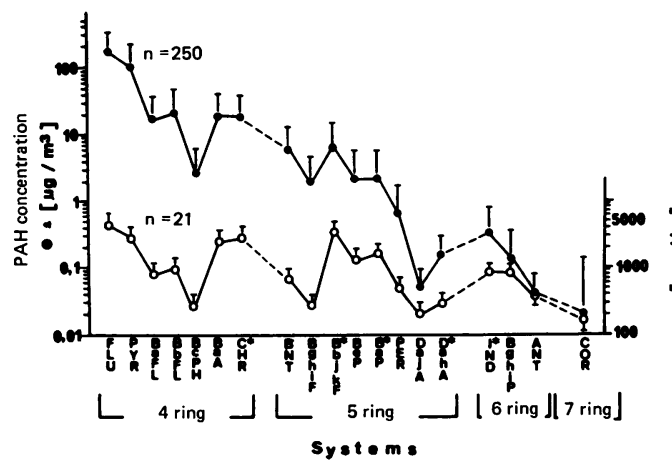

Fig 2 Means and standard deviations $\left[\mu \mathrm{g} / \mathrm{m}^{3}\right]$ of $P A H$ concentrations determined in 250 air samples from work arean of road works during use of tar bitumen as binder, with means? and standard deviations $[\mathrm{mg} / \mathrm{kg}$ ] of $\mathrm{PAH}$ content in 21 tar bitumen asphalt mixes. (See table 1 for abbreviations.) 
sometimes more than $100 \%$ of the means and emphasise the large concentration variations that occurred during the sampling at the place of work. The standard deviations of about $180 \%, 187 \%, 144 \%, 177 \%$, and $700 \%$ recorded for perylene, dibenzo[a,h]anthracene, indeno[1,2,3,-cd]pyrene, benzo[ghi]perylene, and coronene were particularly high. It is true that the mean PAH concentrations of the samples of Carbobitumen are also subject to high standard deviations. But by contrast with the air concentrations of PAH the average deviation from the mean amounted to only about $48 \%$ with a relatively narrow scatter range of $37-59 \%$. Here the extreme PAH concentrations differed by a factor of 5-10. The reasons for the high standard deviation are to be found in the fact that the composition of the tar pitch and bitumen components varies from charge to charge and in the more or less inhomogeneous mixing of the two components.

As expected, the mean PAH concentration over an eight hour working shift was also subject to considerable scatter. The extreme values for the carcinogenic PAH are shown in fig 3; they are referred to benzo[a]pyrene $=1$. Accordingly, dibenzo [a,h]anthracene and indeno[1,2,3-cd]pyrene exhibit the greatest variations. They vary by factors of about 130 and 30 respectively.

As with the paving temperature, the proportion of the pitch component with a high PAH content in the bitumen mix also affects the PAH emission profile during the use of Carbobitumen in road works. As an example, fig 4 presents three PAH profiles for comparison. The eight hour time weighted $\mathrm{PAH}$ averages are shown relating to benzo[a]pyrene $=1$. Profile $\mathrm{A}$ was determined during the use of a binder with a high PAH content of $50.3 \mathrm{~g} / \mathrm{kg}$, the proportion of $\mathrm{BaP}$ was about $0 \cdot 3 \%$. The paving temperature was $120-125^{\circ} \mathrm{C}$. The two other profiles were recorded during paving at

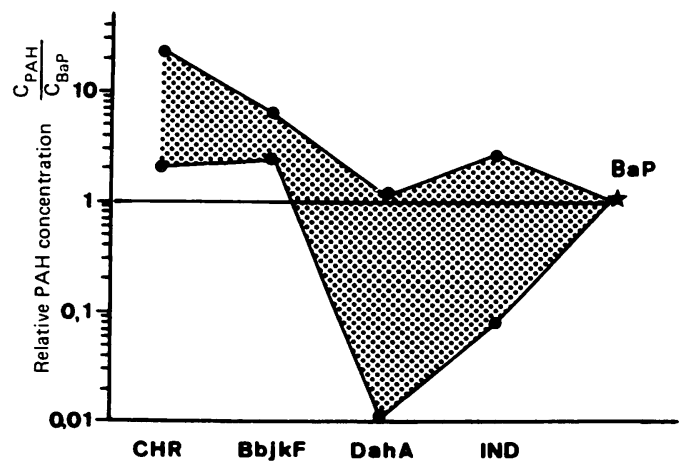

Fig 3 Range in mean shift concentrations, measured on 20 days in work area of road works during use of tar bitumen as binder, of carcinogenic PAH. Results are referred to benzo[a]pyrene ( $\mathrm{BaP}=1)$. (See table 1 for abbreviations.)

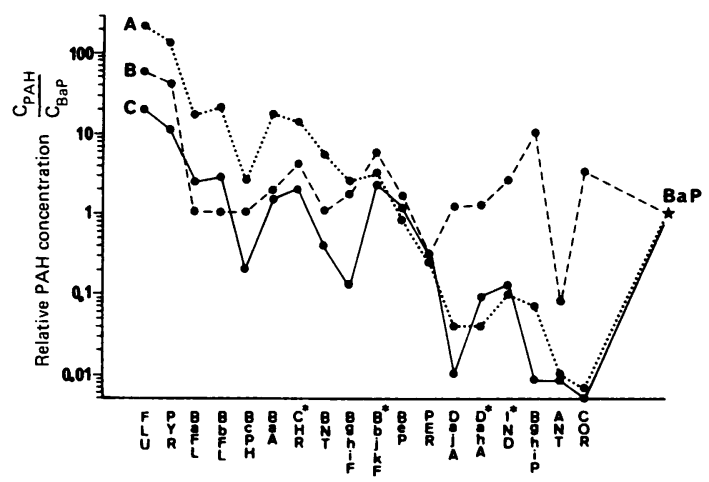

Fig 4 Comparison of profiles of mean shift PAH concentrations in work area of road works during use of tar pitch as binder. Results are referred to benzo[ a]pyrene ( $B a P=1) . A \equiv \Sigma 19 P A H=50 \cdot 3 \mathrm{~g} / \mathrm{kg}$ bitumen mix, $B a P=0.3 \%$; paving temperature $120-125^{\circ} \mathrm{C} . B \equiv \Sigma 19$ $P A H=18.8 \mathrm{~g} / \mathrm{kg}$ bitumen mix, BaP $=0.1 \%$; paving temperature $90-100^{\circ} \mathrm{C} . \mathrm{C} \equiv \Sigma 19 \mathrm{PAH}=18.4 \mathrm{~g} / \mathrm{kg}$ bitumen mix, $B a P=0 \cdot 1 \%$; paving temperature $150-160^{\circ} \mathrm{C}$. (See table 1 for abbreviations.)

the very different temperatures of $97-100^{\circ}$ (profile B) and $150-160^{\circ}$ (profile C). The PAH contents of the binders thus lay in the same order of magnitude at $18 \cdot 8$ and 18.4 respectively. The $\mathrm{BaP}$ concentration was $0.1 \%$ in each case.

Only in some regions is it possible to recognise certain similarities. Thus the results for fluoranthene, pyrene, benzo[c]phenanthrene, chrysene, and benzo[b]naphtho $[2,1-d]$ thiophene give results that are comparable with each other. Profiles $\mathrm{A}$ and $\mathrm{C}$ correspond in addition to each other with respect to the relative concentrations to benezofluorenes, benz[a] anthracene, and benzo[ghi] fluoranthrene. Variations, some considerable, occur in the profile for benzo[e]pyrene. There are extreme variations in the values obtained for the carcinogenic polycyclenes dibenz $[\mathrm{a}, \mathrm{h}]$ anthracene, and indeno[1,2,3-cd]pyrene.

The cumulative frequencies and the total concentration for over 250 samples of the carcinogenic PAH and which, therefore, are to be regarded as being of primary importance from an occupational medical point of view are presented in fig 5. Chrysene and benzo[b,j,k]fluoranthenes, which were determined as the sum, have a median concentration appreciably over $1 \mu \mathrm{g} / \mathrm{m}^{3}$. The medians for benzo[a]pyrene amounted to about 0.7 and for indeno[1,2,3-cd]pyrene $0.2 \mu \mathrm{g} / \mathrm{m}^{3}$. Dibenzo[a,h]anthracene has the lowest median concentration of about $0.03 \mu \mathrm{g} / \mathrm{m}^{3}$ on account of its low volatility. It is also relevant that this PAH compound only accounts, on average, for $1.2 \%$ of the total amount of the 19 PAH determined in the tar bitumen binder. 


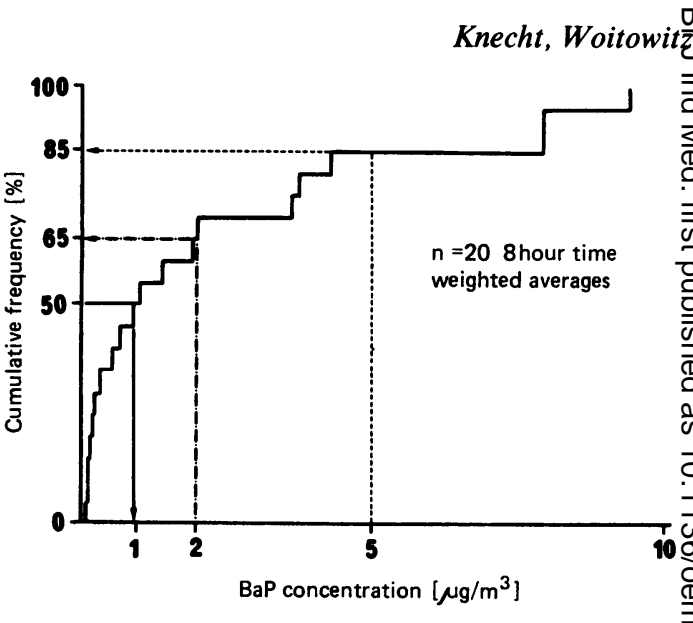

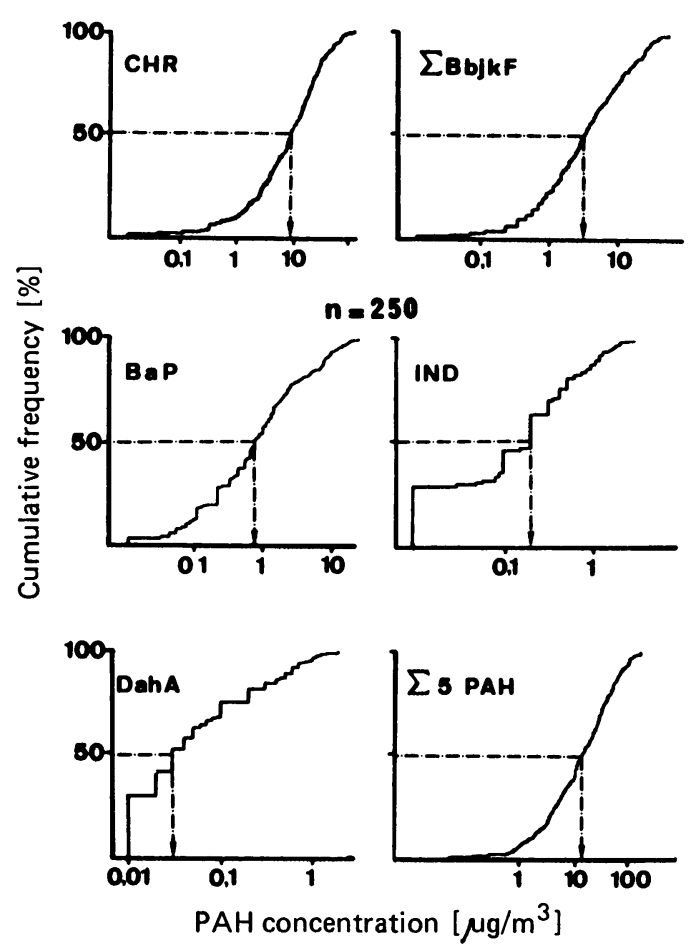

Fig 5 Cumulative frequencies of concentrations $\left[\mu \mathrm{g} / \mathrm{m}^{3}\right]$ of individual PAH and of the sum of the concentrations of five carcinogenic PAH from 250 individual determinations in work area of road works during use of tar bitumen as binder. (See table 1 for abbreviations.)

The health risk for workers who are exposed to PAH may be estimated from the shift mean concentrations obtained from the eight hour day determinations of benzo[a]pyrene on the basis of a threshold for $\mathrm{BaP}$ of $2 \mu \mathrm{g} / \mathrm{m}^{3}$. Figure 6 shows the cumulative frequencies of the average $\mathrm{BaP}$ concentrations established on the 20 days during which determinations were made; more than $50 \%$ of the determined concentrations lie above $1 \mu \mathrm{g} \mathrm{BaP} / \mathrm{m}^{3}$ air breathed. About $35 \%$ of the determinations exceed the threshold of $2 \mu \mathrm{g} / \mathrm{m}^{3}$ as the shift average. The threshold of $5 \mu \mathrm{g} \mathrm{BaP} / \mathrm{m}^{3}$ laid down for short term exposure of one half hour per shift was exceeded in about $15 \%$ of the results obtained.

The influence of the paving temperature of the asphalt mix on the PAH may be seen in table 2 using the $\mathrm{BaP}$ concentration as an example. As expected, the PAH emissions increase with increasing temperature. Even at paving temperatures of $120-135^{\circ} \mathrm{C}, 4.8 \%$ of the measurements lie over the threshold of $2 \mu \mathrm{g} \mathrm{BaP} /$ $\mathrm{m}^{3}$. When the temperature is in the $135-150^{\circ} \mathrm{C}$ range there is an appreciable overstepping of this limit of $34.9 \%$. When the temperature is over $150^{\circ} \mathrm{C}$ the
Fig 6 Cumulative frequency of mean shift benzo[a]pyrene concentrations $\left[\mu \mathrm{g} / \mathrm{m}^{3}\right]$ from 20 days of determination at road works where tar bitumen was used as a binder.

emission behaviour is characterised by high? sometimes very high, BaP concentrations with a median of $3.1 \mu \mathrm{g} / \mathrm{m}^{3}$ and an absolute maximum of $22.0 \mathrm{~g}$ $\mu \mathrm{g} / \mathrm{m}^{3}$.

\section{Discussion}

Epidemiological investigations have shown association in man between tumours and occupatiomap contact with mixtures of PAH..$^{20-22}$ It is not possible $\mathrm{fo}$ investigate the carcinogenic effects of individual ${ }_{\mathbb{N}}$ chemically pure $\mathrm{PAH}$, or mixtures of chemically purê PAH epidemiologically because PAH at the place of work are always accompanied by other products of pyrolysis.

The carcinogenic effects of various PAH in animals have been confirmed many times ${ }^{623}$; the suspicion that. the carcinogenic effect of particulate smokes and pyrolysates principally results from their PAH conten has also been confirmed in animal experiments for coa' smoke particles, particulate motor vehicle emissions $\frac{3}{3}$. and used lubricating oils. ${ }^{24}{ }^{25}$ On the basis of animab

Table 2 Medians and ranges of the emitted benzo[ a Jpyrene $\mathrm{O}$ concentrations $\left(\mu \mathrm{g} / \mathrm{m}^{3}\right)$ and the percentages of them higher than $2 \mu \mathrm{g} / \mathrm{m}^{3}$ as a function of paving temperature of the asphalt mix for samples taken in the work area of road works during the use of tar bitumen as binder

\begin{tabular}{|c|c|c|c|c|}
\hline \multirow{2}{*}{$\begin{array}{l}\text { Paving } \\
\text { temperature of } \\
\text { coal tar } \\
\text { pitch/asphalt } \\
\text { mix }\left({ }^{\circ} \mathrm{C}\right)\end{array}$} & \multicolumn{2}{|c|}{$\begin{array}{l}\text { Benzo }\{\text { a]pyrene } \\
\left(\mu \mathrm{g} / \mathrm{m}^{3}\right)\end{array}$} & \multirow{2}{*}{$\begin{array}{l}\text { Measure- } \\
\text { ments }(n)\end{array}$} & \multirow{2}{*}{$\begin{array}{l}\mathrm{BaP} \\
>2 \mu \mathrm{g} / \mathrm{m}^{3} \\
(\%)\end{array}$} \\
\hline & $\mathrm{Mec}$ & $\tilde{c}$ Range & & \\
\hline $\begin{array}{l}<120 \\
120-135 \\
135-150 \\
>150\end{array}$ & $\begin{array}{l}0 \cdot 2 \\
0 \cdot 5 \\
1 \cdot 2 \\
3 \cdot 1\end{array}$ & $\begin{array}{l}0.01-0.9 \\
0.03-8.1 \\
0.03-17.8 \\
0.3-22.0\end{array}$ & $\begin{array}{l}45 \\
62 \\
86 \\
57\end{array}$ & $\begin{array}{r}- \\
4 \cdot 8 \\
54 \cdot 9 \\
56 \cdot 2\end{array}$ \\
\hline
\end{tabular}


experiments (epicutaneous tests) it has been estimated that $70-100 \%$ of the total carcinogenic effect of these emission condensates results from their PAH content ${ }^{25-27} \mathrm{~A}$ total of about $10 \%$ and $6 \%$ respectively of the carcinogenic potential of the PAH fraction of condensed coal burning and gasoline engine emissions are attributable to their benzo[a]pyrene content, ${ }^{26-28}$ The effect of PAH with more than three rings explains more than $80 \%$ of the carcinogenic effect of motor vehicle exhaust particles (gasoline engines), whereas the effect of benzo[a]pyrene only accounts for $2-3 \%$ of the total. ${ }^{24}$ In the case of the products of combustion of coal fired plants lung implantation in rats yields results similar to those obtained from dermal application in mice. 29

The gene toxicity of numerous PAH has been shown in various short term test systems (see ref 30 , for example.) There is usually a mutagenic effect by which the genetic constitution of cells or bacteria is altered. The extrapolation of such results to man does not, however, envisage altered genetic constitution but carcinogenic cell damage.

From the complex spectrum of gas chromatographically and mass spectroscopically detectable PAH in the atmospheric samples from the workplace during road paving it was possible to determine quantitatively $19 \mathrm{PAH}$, some of which have decidedly carcinogenic properties. Benzo[a]pyrene is of particular importance. Special occupational protection measures are laid down from $2 \mu \mathrm{g} / \mathrm{m}^{3}$ for this substance. ${ }^{31}$ The tar bitumen used in road works has a mean content of $0 \cdot 17 \%$ benzo[a]pyrene. This, together with the mean concentration of $2 \cdot 5 \%$ of all the PAH compounds that could be determined in the investigation, explains the sometimes extremely high atmospheric concentration measured. Thus $50 \%$ of the samples yielded total PAH concentrations of more than $236 \mu \mathrm{g} / \mathrm{m}^{3}$; this included a contribution of $14 \mu \mathrm{g} /$ $\mathrm{m}^{3}$ from the five PAH that have unequivocally been shown to be carcinogenic. In $10 \%$ of the samples these five PAH amounted to more than $100 \mu \mathrm{g} / \mathrm{m}^{3}$ and amounted to about $11 \%$ of the total PAH concentration.

Bjørseth et al have studied highly contaminated places of work in aluminium production and in coke works by making large numbers of determinations of PAH emission. ${ }^{32} 33$ According to these authors the mean total concentrations of 14 comparable PAH determined on the oven tops of a coke works are about twice as high as the corresponding mean concentrations of $366 \mu \mathrm{g} / \mathrm{m}^{3}$ determined when using tar bitumen in road works. The ratios in the work area of the "vertical pin Søderberg" plant in aluminium production are virtually reversed. Here the sums of the concentrations of 14 PAH amounted to about $194 \mu \mathrm{g} /$ $\mathrm{m}^{3}$. It is true that at 46 and $5 \mu \mathrm{g} / \mathrm{m}^{3}$ respectively the mean $\mathrm{BaP}$ concentrations at workplaces in the coke works and aluminium production plant are appreciably higher than the mean concentration of $2.2 \mu \mathrm{g} / \mathrm{m}^{3}$ determined for the road works. Nevertheless, a maximum BaP concentration of $22 \mu \mathrm{g} / \mathrm{m}^{3}$ and concentrations of over $10 \mu \mathrm{g} / \mathrm{m}^{3}$ in $10 \%$ of cases make it necessary to classify the work area in road building as just as strongly potentially carcinogenic when tar bitumen binder is used as the above mentioned places of work in coke works and aluminium production plants. The paving temperature of the asphalt mix has a decisive effect on the level of the PAH emissions. Even when the temperature was in the range 120 $135^{\circ} \mathrm{C}$ three of 62 samples (三4.8\%) had concentrations greater than $2 \mu \mathrm{g} \mathrm{BaP} / \mathrm{m}^{3}$. The measured concentration of $8.1 \mu \mathrm{g} \mathrm{BaP} / \mathrm{m}^{3}$ must be regarded as being particularly high. In all, 33 of the 193 results obtained at temperatures below the maximum recommended operating temperature of $150^{\circ} \mathrm{C}$ exceeded $2 \mu \mathrm{g} / \mathrm{m}^{3}$. It had previously been assumed on technical grounds that paving with tar bitumen using mechanical paving machines and paving temperatures $<150^{\circ} \mathrm{C}$ would lead to $\mathrm{BaP}$ concentrations lower than $2 \mu \mathrm{g} / \mathrm{m}^{3} .{ }^{34}$ The BaP concentrations reported here have shown this assumption to be in need of correction. As the investigations also proved, paving temperatures higher than $150^{\circ} \mathrm{C}$ occur not infrequently (in $23 \%$ of the cases investigated here). This leads to intense exposure of the workers to PAH emissions.

Comparative investigations of various places of work in coke works and aluminium production plants have shown a great constancy and agreement in the PAH profiles of the characteristic PAH emissions. ${ }^{32} 333536$ For this reason some authors have regarded it as being sufficient to determine one reference component, such as $\mathrm{BaP}$, as representative of the total carcinogenic effect of the total PAH spectrum. This is not satisfactory from an occupational medical oncological point of view. The criterion of exceeding or not exceeding a BaP concentration of $2 \mu \mathrm{g} / \mathrm{m}^{3}$ taken as a references substance does not adequately represent the carcinogenic risk in the work areas engaged in road works. Factors such as, for instance, the daily changing paving temperatures of the asphalt mix and the highly variable pitch content of the binder lead to variations in the PAH content of the daily profile which may sometimes be considerable. It thus seems to us appropriate here to at least determine the spectrum of unequivocally carcinogenic as well as of cocarcinogenic and tumour promoting PAH. It is sufficiently well known that some compounds - for example, fluoranthene and pyrene-can multiply the carcinogenic effect of benzo[a]pyrene several fold..$^{37}$ The continued use of tar bitumen in road works should be questioned and consideration should be given as to whether this 
product can be replaced as a binder for bituminous asphalt mix.

Supported by the Bundesministerium für Forschung und Technologie of the Federal Republic of Germany Project No 01 VD 093.

\section{References}

1 Lindstedt G, Sollenberg J. Polycyclic aromatic hydrocarbons in the occupational environment. Scand J Work Environ Health 1982;8:1-19.

2 Gammage RB. Polycyclic aromatic hydrocarbons in work atmospheres. In: Bjørseth A, ed. Handbook of polycyclic aromatic hydrocarbons. New York, Basel: M Dekker, Inc, 1983:653-707.

3 International Agency for Research on Cancer. Monographs on the evaluation of the carcinogenic risk of chemicals to humans. Vol. 34. Part 3.Polynuclear aromatic compounds. Lyon: IARC, 1984.

4 Knecht U, Elliehausen HJ, Woitowitz HJ. Gaseous and adsorbed PAH in an iron foundry. Br J Ind Med 1986;43:834-8.

5 Commission for investigation of health hazards of chemical compounds in the work area. DFG German Science Foundation. Maximum concentrations in the workplace and biological tolerance values for working materials. Weinheim: Verlag Chemie, 1987. (Report No XXIII.)

6 International Agency for Research on Cancer. Monographs on the evaluation of the carcinogenic risk of chemicals to humans. Vol 32. Part 1. Polynuclear aromatic compounds. Lyon: IARC, 1983.

7 Yamagiwa K, Ichikawa K. Experimental study on the pathogenesis of epithelial tumours. Mitteilungen der Medizinischen Fakultät der Kaiserlichen Universität Tokyo 1915;15:295-344.

8 Cook JW, Hieger I, Kennaway EL, Mayneord WV. The production of cancer by pure hydrocarbons: Part 1. Proc R Soc London 1932; Ser B 3: 455-84.

9 Cook JW, Hewett CL, Hieger I. The isolation of a cancerproducing hydrocarbon from coal tar. Journal of the Chemical Society 1933;398:395-405.

10 Tobias S, Knecht U, Woitowitz HJ. Temperaturabhängigkeit experimentell emittierter polycyclischer aromatischer Kohlenwasserstoffe (PAH) aus Straßenbaubindemitteln. In: Szadkowski D, ed. Verhandlungen der Deutschen Gesellschaft für Arbeitsmedizin. Stuttgart: Gentner Verlag 1986:279-82.

11 DIN Deutsches Institut für Normung. Bitumen and coal tar pitch; terms and definitions for coal tar pitch and preparations from special coal tar pitch. Berlin: Beuth Verlag, 1983. (DIN 55946 Teil 2.)

12 Tobias S, Knecht U, Woitowitz HJ. Polycyclische aromatische Kohlenwasserstoffe in Straßenbaumaterialien: Beitrag zu einer arbeitsmedizinisch-retrospektiven Risikoabschätzung. In: Bolt HM, Piekarski C, Rutenfranz J, eds. Verhandlungen der Deutschen Gesellschaft für Arbeitsmedizin. Stuttgart: Gentner Verlag, 1985;547-52.

13 Ausschuß für Gefahrstoffe (AGS). Technische Regeln für Gefahrstoffe TRGS 402. Ermittlung und Beurteilung der Konzentrationen gefährlicher Stoffe in der Luft an Arbeitsbereichen. Bundesarbeitsblatt 1986;11:92-6.

14 Murray JJ, Pottie RF, Pupp C. The vapor pressures and enthalpies of sublimation of five polycyclic aromatic hydrocarbons. Canadian Journal of Chemistry 1974;52:557-63.

15 Pupp C, Lao RC, Murray JJ, Pottie RF. Equilibrium vapour concentrations of some polycyclic aromatic hydrocarbons, $\mathrm{As}_{4} \mathrm{O}_{6}$ and $\mathrm{SeO}_{2}$ and the collection efficiencies of these air pollutants. Atmospheric Environment 1974;8:915-25.

16 Knecht U, Lämmler C, Tobias S. Evaluation of various collection phases for polycyclic aromatic hydrocarbons (PAH). Fresenius Zeitschrift für Analytische Chemie 1987;326:25-32.

17 Grimmer G, Böhnke H. Gas chromatographic profile analysis of polycyclic aromatic hydrocarbons in lubricating oil, cutting oil and fuel. (No 29.) Lyon: International Agency for Research on Cancer, 1979;155-73.

18 Griest WH, Caton JE. Extraction of polycyclic aromatic hydrocarbons for quantitative analysis. In: Bjørseth $\mathrm{A}$, ed. Handbook of polycyclic aromatic hydrocarbons. New York,
Basel: M Dekker, Inc, 1983:94-148.

19 Van Cauwenberghe K, Van Vaeck L. Modern PAH-analysis and fate of PAH in air. In: Rondia D, Cook M, Haroz RK, 函. Mobile source emissions including polycyclic organic specks. Dordrecht, Boston, Lancaster: D Reidel, 1983:327-47.

20 Doll R, Vessey MP, Beasley RWR, et al. Mortality of $\overrightarrow{\text { gas- }}$ workers-final report of a prospective study. $\mathrm{Br} J$ Ind $\mathrm{Mted}$ 1972;29:394-406.

21 Alderson M. Occupational cancer. London: Butterworth \& $\bar{\sigma}_{0}$ 1986:101-10.

$22 \mathrm{Manz}$ A. Respiratory and urinary tract as indicator $\frac{\mathbb{D}^{\circ}}{\mathrm{f}}$ occupational (coal-tar) carcinomas in carbonisation and pme workers. In: Werner W, Schneider HW, eds. Air contamina by polycyclic aromatic hydrocarbons (Ger). Düsseldorf: Verein Deutscher Ingenieure VDI, 1980:227-35. (No 358).

23 Grimmer G, ed. Environmental carcinogens: polycyclic aromatic hydrocarbons. Boca Raton, Florida: CRC Press, Inc, 1983. $\vec{\omega}$

24 Grimmer G, Brune H, Deutsch-Wenzel R, Dettbarn G, MisfelकPJ. Contribution of polycyclic aromatic hydrocarbons to fie carcinogenic impact of gasoline engine exhaust condensigte evaluated by implementation into the lungs of rats. $J$ hat Cancer Inst 1984;72:733-9.

25 Grimmer G, Dettbarn G, Brune H, Deutsch-Wenzel R, MisfeldtJ. Quantification of the carcinogenic effect of polycyclic arom hydrocarbons in used engine oil by topical application onto the skin of mice. Int Arch Occup Environ Health 1982;50:95-109.

26 Grimmer G, Brune H, Deutsch-Wenzel R, Nâujack KW, Misfełd J, Timm J. On the contribution of polycyclic aromatic hydrokgrbons to the carcinogenic impact of automobile exhaust condensate evaluated by local application onto mouse skin. Cancer 1983;21:105-13.

27 Misfeld J, Timm J. The tumor-producing effects of automobile exhaust condensate and fractions thereof Part III: M 4 hematical-statistical evaluation of the test results. $J$ Envion Pathol Toxicol 1978;1:747-72.

28 Brune H. Experimental results with percutaneous applicatiunoof automobile exhaust condensates in mice. In: Mohr U, बir pollution and cancer in man. Lyon; International Agenty for Research on Cancer 1977;41-7. (Sci publ No 16.)

29 Pott F, Stöber W. Carcinogenicity of airborne combus products observed in subcutaneous tissue and lungs 0 of laboratory rodents. Environ Health Perspect 1983;47:243-3

30 Deutsch-Wenzel R, Brune H. Carcinogenicity-short-term tests In: Grimmer G, ed. Environmental carcinogens: polycychic aromatic hydrocarbons. Boca Raton, Florida: CRC Press, 商, 1983:161-78.

31 Ausschuß für Gefahrstoffe. Verordnung über gefährliç大 Stoffe-Gefahrstoffverordnung-GefStoffV. Bundesges $\mathrm{ez}_{z}$ blatt 1986;1:1470-87.

32 Bjørseth A, Bjørseth $\mathrm{O}$, Fjeldstad PE. Polycyclic arom hydrocarbons in the work atmosphere. I. Determination ifan aluminium reduction plant. Scand $J$ Work Environ Hegith $1978 ; 4: 212-23$.

33 Bjørseth A, Bjørseth O, Fjeldstad PE. Polycyclic aromatic hydrocarbons in the work atmosphere. II. Determination a coke plant. Scand J Work Environ Health 1978;4:224-36.

34 Ausschuß für gefährliche Arbeitsstoffe. Technische Regeln Gür gefährliche Arbeitsstoffe-Auslöseschwelle für Benzo[a]py pen (TRgA 126). Cologne: C Heymanns Verlag, 1986:1-5.

35 Bjørseth A, Bjørseth O, Fjeldstad PE. Polycyclic aromatic hydrocarbons in the work atmosphere. Determination of afed specific concentrations and job-specific exposure in a vertical pin Söderberg aluminium plant. Scand $J$ Work Environ Healih 1981;7:223-32.

36 Blome H, Bans K. Konzentrationen polyzyklischer aromatiseher Kohlenwasserstoffe (PAH) bei Hertstellung und Verwend von Pyrolyseprodukten aus organischem Material. Stano Reinhalt Luft 1983;43:367-72.

37 Hoffmann D, Schmeltz J, Hecht SS, Wynder EL. Tobacto carcinogenesis. In: Gelbain AV, ed. Polycyclic hydrocarbons and cancer. Vol 1. New York: Academic Press, 1978:85-117. (D)

38 Van Duuren BL, Goldschmidt BM. Cocarcinogenic and tumfirpromoting agents in tobacco carcinogenesis. J Natl Cancer $\mathrm{As}$ 1976;56:1237-42. 